ВЕРТИЕВЕЦ Оксана Анатольевна старший преподаватель кафедры экономики и информационных технологий Краснодарского государственного института культуры

Краснодар, Российская Федерация Oksana A. VERTIYEVETS

Senior Lecturer, Department of Economics and Information Technologies, Krasnodar State Institute of Culture, Krasnodar, Russian Federation magda76@mail.ru

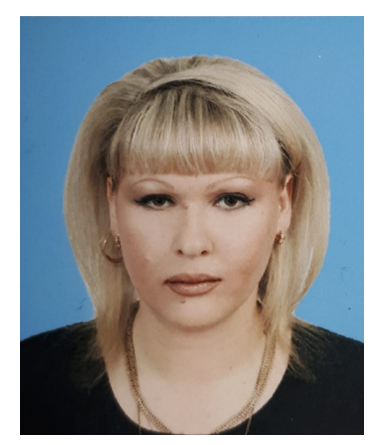

\section{Социально-информационное конструирование и информационная культура современного российского общества}

\author{
Social Information Design \\ and Information Culture \\ of Modern Russian Society
}

Социальное конструирование в информационно-коммуникативной сфере является важнейшим элементом современного информационно-коммуникативного пространства. Лавинообразное увеличение объемов информации и коммуникативных взаимодействий сформировало информационно-коммуникативные потоки, захлестнувшие человека. Это расширило рамки используемых им социокультурных паттернов. Включенность в потоковые информационно-коммуникативные структуры значительно сократило возможности рефлексивного осмысления и переработки получаемой информации, внедрив в современные информационно-коммуникативные практики пассивно-созерцательные схемы восприятия. В статье раскрываются и анализируются модели социального конструирования в информационно-коммуникативном поле - стратегии и технологии мифологизации и симулякризации информации, направленной на управляющее ментальное воздействие в сфере индивидуального сознания отдельных людей, образующих целевые аудитории, и на общественное сознание выделенных сообществ со сходными идентификационными признаками целевых групп.

Ключевые слова: повседневность, протоколы социальных действий, алгоритмы социальных действий, предписанты, фреймы, социально-коммуникативное пространство, информационная культура. 
Современный человек воспринимает окружающий мир не только и не столько на основании личного опыта, который в условиях профессиональной специализации и детализации алгоритмов профессиональной деятельности в условиях распространения массовых однотипных операций свелся к достаточно узкой по возможностям когнитивной составляющей в повседневности, ретранслируемой сквозь фильтры средств массовых коммуникаций - от телевизионных и радиопередач до социальных сетей. Проживая повседневность в ситуации всеобщего распространения протоколов и алгоритмов, современные потребители информации оказались включенными в социально-коммуникативное пространство, направленное на формирование общего консенсуса $[1$, с. 30]. Это социально-коммуникативное пространство основано на отборе фактов, их трансформации при интерпретации и формировании интегрирующей и консолидирующей целевую аудиторию системой предписанных суждений и оценок.

Ускорение темпоритмов протекания социальных процессов, лавинообразное увеличение потоков информации, многообразие каналов коммуникации, к которым «подключен» человек, привели к укоренению фреймов моментальной реакции на происходящие в окружающей среде события, превратив выбор социальных действий в мгновенную реакцию, основанную на практически подсознательном выборе той или иной модели действия, укорененной в индивидуальном и коллективном бессознательном.

Такая ситуация актуализировала значение общего для данного социума социально-коммуникативного пространства, снизив порог проверки репрезентативности и релевантности получаемой людьми информации, ускорив обмен информацией внутри социально-сетевых групп и став средством санкционирования предписываемых соответствующей моделью ситуации и ее распознаванием действий акторов социально-коммуникативных процессов. При этом чем большее коммуникативное подкрепление получает такая информация («общественный резонанс»), тем активнее действуют люди и социальные институты.
В условиях асимметрии распределения и интерпретации информации в обществе происходит гомогенизация смыслов, которые формируются под влиянием неполноты информационной картины происходящих событий на основе явления, называемого когнитивным диссонансом. Известное, обыденное, во многом превратившееся в рутину и утратившее свою привлекательность, активно вытесняется эмоционально окрашенными аллюзиями и метафорами, содержащимися в сообщениях, созданных в рамках процессов социального конструирования событий, подвергшихся мифологизации с целью их упрощения для восприятия массовой аудиторией и в соответствии с ее информационно-коммуникативными предпочтениями, выраженными в доступной форме, или «простыми словами».

В мифологизированной информации отношения в описываемых событиях отождествляются с унифицированными, символически означенными образами, задающими рамки санкционированных отношений и норм, представлений и их последствий. При этом событийные сценарии, которые имеют предписанные для целевой аудитории означивания, с одной стороны, характеризуются устойчивой, обусловленной инерционностью культуры структурой и определенным исторически сложившимися в данном обществе стереотипами вектором развития сюжетных линий, а с другой стороны, содержат фрагменты инновационности, призванные адаптировать эволюцию закрепленного в сознании мифологически релевантного к новым социально-культурным условиям и исторически проявившимся новым тенденциям социального развития, новым социально-культурным практикам, которые представлены в виде гиперреального Ж. Бодрийяра. Инновационное, не до конца оформленное и не полностью осмысленное, выступает в форме незавершенного проекта наступающего будущего, которое представляет собой некий «синтетический продукт, излучаемый комбинаторными моделями в безвоздушное гиперпространство» $[5$, с. 11$]$.

Все приобретенное человеком посредством включенности в повседневные межлич- 
ностные взаимодействия в современном информатизирующемся обществе вытесняется вербально-визуальным наблюдением за смоделированными «жизненными» ситуациями и проблемами, представляемыми коммуникативной реальностью. Под коммуникативной реальностью условимся понимать визуально иллюстрированное описание событий и жизненных коллизий в средствах массовой информации, порождающих медиареальность, и социальных сетях в интернет-пространстве, в которых распространены социально-ролевые повествования, основанные как на субъективно описанных и трансформированных в расчете на ознакомление с ними широкой аудитории реальных событиях, так и на сконструированных из элементов реальности и заимствованных из различных источников информации контамированных описаний событий, напоминающих реальность, обладающих большинством признаков реальных событий, но не являющихся реальными событиями [4, c. 653-655].

Симулякры призваны интегрировать социально-информационное поведение целевых аудиторий, выделив в индивидуальной информационной культуре представителей целевой аудитории гомогенные оценки в восприятии нацеленных на нее средств массовой коммуникации и вызвав явление резонанса, в процессе которого каждый актор социально-коммуникативного процесса, участвующий в получении, интерпретации и распространении нацеленной на него информации, участвует и в создании синергетического эффекта воздействия, многократно усиливая эмоциональную окраску сконструированного события. В результате создается социально-коммуникативное поле с высоким эмоциональным напряжением, которое продуцирует эмоциональное эхо в общественном мнении целевой группы эмоциональный резонанс, основанный, с одной стороны, на усреднении общественного мнения, а с другой - на многократном усилении эмоционального воздействия и эмпатии к воспринятой в качестве нормативно приемлемой интерпретации социально-коммуникативного конструкта. При этом создаваемый в процессе когнитивной и рефлексивной переработки конкретным человеком информации, которую несет социально-коммуникативный конструкт, индивид корректирует свои ментальные оценки с доминантными оценками предписантов - авторитетных публичных персон, экспертов в области деятельности, которую затрагивает симулякр.

В процессе отбора информации в информационных потоках в условиях априорного доверия к определенным источникам информации происходит процесс «навязывания повестки дня», то есть ранжирования информации по важности на основе конструктивистских планов ее создателей. В рамках этого процесса происходит структурация когнитивной деятельности целевых аудиторий и корректировка их когнитивных возможностей. В результате информация, противоречащая навязываемой интерпретации, отвергается как ложная и несущественная и означенная таким образом исключается из социально-коммуникативного дискурса. Способность к самостоятельному определению репрезентативности и валидности информации является частью информационных компетенций человека и, шире, частью его информационной культуры.

Информационная культура в дискурсе культурологической парадигмы рассматривается как значимый системный элемент духовной культуры современного российского общества [3]. Современная информационная культура российского общества характеризуется мозаичностью и фрагментированностью уровня развития в различных регионах в силу асимметричности распределения человеческих, технологических и финансовых ресурсов. Поэтому в целях преодоления ощущения энклюзивности и аутсайдерства в сфере формирования элементов информационного общества с распространением доступных мобильных коммуникативных устройств во многих социально-демографических группах, прежде всего среди молодежи, распространились виртуализация и симулякризация восприятия событий в окружающем мире, особенно в области медиакультуры и сетевых социально-коммуникативных практик [2].

Следовательно, современное восприятие реальности в информационно-коммуникативном поле людьми построено на адапти- 
рующих к коллективному усредненному общественному мнению схемах, частично конструирующих и дополняющих картину окружающего мира с учетом личного опыта человека и условий его укорененности в сообществе, к которому он принадлежит. А это, в свою очередь, во многом предопределяет не только его отношение к окружающей внешней среде, но и мотивы и установки его социального поведения в настоящем и будущем, а также оценки им прошлого.
Отсутствие персонального опыта проживания различных социокультурных практик формирует в различных социально-демографических группах потребность в присоединении кдоминирующему в данной возрастной группе описанию окружающей действительности в соответствии с эффектом присоединения Веблена, подкрепленную информационно-коммуникативными потоками, с мейнстримом которых идентифицирует себя данное сообщество.

\section{Oksana A. VERTIYEVETS \\ Social Information Design and Information Culture of Modern Russian Society}

Abstract. Modern people, immersed in intensive information and communication flows, do not perceive the surrounding world on the basis of personal experience, subordinated to the algorithmized authorized requirements of the normative value system of the society. They perceive it through these flows' determination by protocols and algorithms of everyday sociocultural practices and mental schemes - frames, focused on maintaining social consensus. The actualization of the mental algorithms and schemes, sanctioned in the community and integrated in the common information and communication field in the context of information redundancy, has led to the predominance of subconscious immediate reactions to what is happening in the environment of the event; thus, the choice of social actions becomes an instant reaction based on the choice of a particular model of social action, and this choice is actually "prescribed" by the collective unconscious. Under these conditions, the more communicative support in the form of repetitions, judgments of various experts and analysts such information receives ("public response"), the more active people and social institutions act in the given vector of social activity. The preservation and deepening of the asymmetry of distribution and interpretation of information in society results in the homogenization of meanings. The perception of the outside world based on personal experience is replaced by a visually illustrated description of events and life conflicts in the media that generate mediareality, including in social networks in the Internet space. Social roleplaying narratives are common there. The result is a socio-communicative field with high emotional stress, which produces an emotional echo in the public opinion of the target group - emotional ressponse based, on the one hand, on the averaging of public opinion and, on the other hand, on the multiple strengthening of emotional impact and empathy to the interpretation, perceived as normative and acceptable, of a social and communicative construct that is designed to integrate the target audience of the information and communicative impact. Therefore, people's modern perception of reality in the information and communication field is constructed on the schemes that adapt people to a collective average public opinion and partially design and supplement the image of the world around with the use of factoids taking into account people's personal experience and conditions of their rootedness in community to which they belong, according to the Veblen effect.

Keywords: everyday life, protocols of social actions, algorithms of social actions, prescribed, frames, social and communicative space, information culture.

\section{Использованная литература:}

1. Бурдье П. О телевидении и журналистике. М.: Прагматика культуры, 2002.
References:

1. Bourdieu, P. (2002) O televidenii i zhurnalistike [On television and journalism]. Translated from French. Moscow: 
2. Воронкова О. А. Массовое сознание в новых информационных условиях: возможности манипуляции и ресурсы противодействия // Дискуссионные проблемы социальной психологии: коллективная монография / Отв. ред. А. Ю. Нагорнова. Ульяновск: Зебра. 2018. С. 4760.

3. Забокрицкая Л. Д. Информационная культура современной молодежи: Угрозы и вызовы современного виртуального пространства // Вестник Пермского национального исследовательского политехнического университета. Социально-экономические науки. 2017. №4. C.114-123.

4. Сиразетдинова М. Ф. Симулякр как средство манипуляции сознанием [Электронный ресурс] // Молодой ученый. 2015. №2. C.653-655. URL: https://moluch.ru/ archive/82/14902/ (дата обращения: 18.06.19).

5. Bell D. The Coming of Post-Industrial Society. New York: Basic books, 1976.
Pragmatika kul'tury.

2. Voronkova, O.A. (2018) Massovoe soznanie vnovykh informatsionnykh usloviyakh: vozmozhnosti manipulyatsii i resursy protivodeystviya [Mass consciousness in new informational conditions: possibilities of manipulation and resources for counteraction]. In: Nagornova, A.Yu. (ed.) Diskussionnye problemy sotsial'noy psikhologii [Discussion problems of social psychology]. Ul'yanovsk: Zebra.

3. Zabokritskaya, L.D. (2017) Information culture of modern youth: Threats and challenges of modern virtual space. Vestnik Permskogo natsional'nogo issledovatel'skogo politekhnicheskogo universiteta. Sotsial'no-ekonomicheskie nauki - PNRPU Sociology and Economics Bulletin. 4. pp. 114123. (In Russian). DOI: 10.15593/2224-9354/2017.4.10

4. Sirazetdinova, M.F. (2015) Simulyakr kak sredstvo manipulyatsii soznaniem [Simulacrum as a means of manipulating consciousness]. Molodoy uchenyy. 2. pp. 653-655. [Online] Available from: https://moluch.ru/ archive/82/14902/. (Accessed: 18.06.2019).

5. Bell, D. (1976) The Coming of Post-Industrial Society. New York: Basic books.

\section{Полная библиографическая ссылка на статью:}

Вертиевец, О. А. Социально-информационное конструирование и информационная культура современного российского общества [Электронный ресурс] / О. А. Вертиевец // Наследие веков. - 2019. - № 3. - С. 69-73. DOI: 10.36343/ SB.2019.19.3.006

\section{Full bibliographic reference to the article:}

Vertievets, O. A. (2019) Social Information Design and Information Culture of Modern Russian Society. Nasledie vekov Heritage of Centuries. 3. pp. 69-73. (In Russian). DOI: 10.36343/SB.2019.19.3.006 